\title{
Evaluation of cell binding to collagen and gelatin: a study of the effect of 2D and 3D architecture and surface chemistry
}

\author{
Natalia Davidenko ${ }^{1} \cdot$ Carlos F. Schuster $^{1} \cdot$ Daniel V. Bax ${ }^{1} \cdot$ Richard W. Farndale $^{2} \cdot$ \\ Samir Hamaia $^{2} \cdot$ Serena M. Best $^{1} \cdot$ Ruth E. Cameron $^{1}$
}

Received: 16 June 2016 / Accepted: 3 August 2016 / Published online: 31 August 2016

(C) The Author(s) 2016, corrected publication March 2018

\begin{abstract}
Studies of cell attachment to collagen-based materials often ignore details of the binding mechanismsbe they integrin-mediated or non-specific. In this work, we have used collagen and gelatin-based substrates with different dimensional characteristics (monolayers, thin films and porous scaffolds) in order to establish the influence of composition, crosslinking (using carbodiimide) treatment and 2D or 3D architecture on integrin-mediated cell adhesion. By varying receptor expression, using cells with collagen-binding integrins (HT1080 and C2C12 L3 cell lines, expressing $\alpha 2 \beta 1$, and Rugli expressing $\alpha 1 \beta 1$ ) and a parent cell line $\mathrm{C} 2 \mathrm{C} 12$ with gelatin-binding receptors ( $\alpha \mathrm{v} \beta 3$ and $\alpha 5 \beta 1$ ), the nature of integrin binding sites was studied in order to explain the bioactivity of different protein formulations. We have shown that alteration of the chemical identity, conformation and availability of free binding motifs (GxOGER and RGD), resulting from addition of gelatin to collagen and crosslinking, have a profound effect on the ability of cells to adhere to these formulations. Carbodiimide crosslinking ablates integrin-dependent cell activity on both two-dimensional and three-dimensional architectures while the three-dimensional scaffold structure also leads to a high level of non-specific interactions remaining on three-dimensional samples even after a
\end{abstract}

The original version of this article was revised: the copyright was wrong in the PDF version of the article and the Open Access license terms were missing.

Natalia Davidenko nd313@cam.ac.uk

1 Department of Materials Science and Metallurgy, University of Cambridge, 27 Charles Babbage Road, Cambridge CB3 0FS, UK

2 Department of Biochemistry, University of Cambridge, Downing Site, Cambridge CB2 1QW, UK rigorous washing regime. This phenomenon, promoted by crosslinking, and attributed to cell entrapment, should be considered in any assessment of the biological activity of three-dimensional substrates. Spreading data confirm the importance of integrin-mediated cell engagement for further cell activity on collagen-based compositions. In this work, we provide a simple, but effective, means of deconvoluting the effects of chemistry and dimensional characteristics of a substrate, on the cell activity of protein-derived materials, which should assist in tailoring their biological properties for specific tissue engineering applications.

\section{Graphical Abstract}

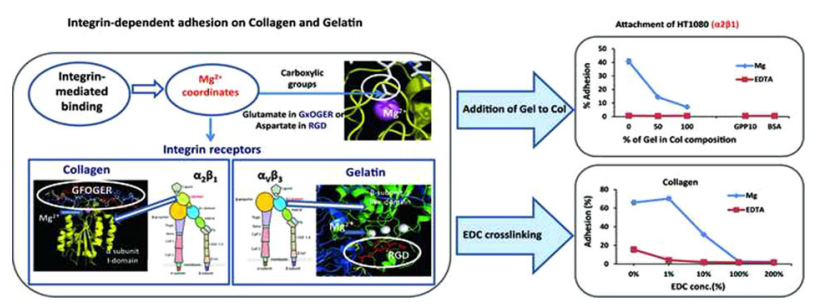

\section{Introduction}

The extracellular matrix (ECM) of tissues provides mechanical support for cells and supplies correct biological signals for cell activity [1-4]. When used as cell-delivery vehicles in tissue engineering (TE) applications, biopolymer scaffolds should mimic these ECM functions. Biological performance of three-dimensional (3D) matrices are influenced by several parameters such as the nature and availability of cell binding ligands, the chemico-physical 
(swelling profiles, degradation rates, etc.) and mechanical properties of the scaffold material and the morphology and spatial characteristics of its 3D structure, including mean pore size, interconnectivity, and homogeneity or anisotropy of inner architecture [3, 5-10]. It is important that the contribution of each of these properties to the overall biological activity of scaffolds is characterised to improve the performance of bioconstructs towards different cell lines.

Over recent years, intensive research has been conducted aimed at creating tailor-made 3D scaffolds. These have been based on collagen $(\mathrm{Col})$ and other biomolecules for a wide variety of tissue repair and regeneration applications including tendon [11], cartilage [12], mammary gland [13], and myocardial tissue $[14,15]$. In this work, Col and Gel (Gel) were selected as base proteins for biopolymer scaffolds. Col, in particular fibrillar Type I, is the most abundant constituent of the ECM of many hard and soft tissues in the human body [2, 16-19]. This protein provides both the structural support to resident cells and also important cell surface receptor-recognition motifs that are essential for cell-substrate interaction [20-22]. Gel is produced by heating Col, which unfolds the triple-helical conformation present in Col, with the formation of random-coiled domains [23, 24]. As such, Gel possesses a very similar chemical composition to Col, but a less ordered macromolecular structure. The addition of Gel to Col and the variation in crosslinking status can tailor many important material properties of resultant matrices. These include the dissolution resistance in different biological environments, the swelling characteristics and the mechanical strength [15, 25]. In conjunction with this data, the main objective of this research is to evaluate cell interaction with Col and Gel-based biomaterials with a particular focus on the chemical identity and availability of receptor recognition ligands for cell adhesion. In the literature, many studies of cell attachment to protein-derived matrices ignore the detailed mechanism of binding - be it integrin-mediated or non-specific. Integrins are a class of heterodimeric transmembrane cell receptors, composed of one $\alpha$ subunit and one $\beta$ subunit, that mediate cell-cell and cell-ECM interactions [26, 27]. In this work, we have used a range of model cell lines which express different integrins. Using cell adhesion analysis of these cell lines we have probed the nature of the integrin binding sites on our materials as a function of biopolymer composition, degree of crosslinking, and two-dimensional (2D) or 3D architecture of the substrate.

In our previous studies, we used UV irradiation and carbodiimide chemistry, based on the reaction with EDC (1ethyl-3-(3-dimethylaminopropyl-carbodiimide hydrochloride) in the presence of NHS (N-hydroxy-succinimide), to tailor the physical characteristics of scaffolds [15, 25].
EDC crosslinking is a very effective method to increase the mechanical stability and the dissolution resistance of collagenous materials [28-31]. However, this treatment consumes the carboxylate groups on the amino acid side chains of glutamate (E) or aspartate (D). This same chemistry is crucial for ligation by the cell surface integrins [15, 32, 33] as both $\mathrm{Col}$ and Gel possess $\mathrm{E}$ or $\mathrm{D}$ residues in their essential cell-recognition motifs. In Col, these cell binding motifs include the high affinity triple-helical GxOGER sequences (where $\mathrm{G}$ is glycine; $\mathrm{O}$ is hydroxyproline; $\mathrm{R}$ is arginine, and $\mathbf{x}$ is hydrophobic, exemplified by phenylalanine, F). By contrast Gel contains the linear RGD cell adhesive motif. Col-derived triple-helical ligands such as GxOGER interact with cells via the $\beta_{1}$-containing integrins, $\alpha_{1} \beta_{1}, \alpha_{2} \beta_{1}, \alpha_{10} \beta_{1}$ and $\alpha_{11} \beta_{1}$ [20-22, 34]. The main receptorrecognition motif of Gel, RGD, ligates several integrins, but primarily $\alpha_{5} \beta_{1}$ and $\alpha_{v} \beta_{3}[24,35]$. The binding of integrins to $\mathrm{Col}$ and Gel requires the presence of divalent cations, and $\mathrm{Mg}^{2+}$ is the preferred physiological ion [36-38]. Cellular interactions with $\mathrm{Col}$ and $\mathrm{Gel}$ are schematically presented in Fig. 1. The mechanistic aspects of cell attachment to Col and Gel substrates suggest that changes in composition and in crosslinking status could alter the nature and the availability of cell-recognition sites, thereby affecting the biological reactivity of these materials.

Figure 2 represents crystal structures of the integrin domains responsible for the integrin-promoted binding to Col triple helical GFOGER sequences and to Gel cyclic RGD binding motif.

To deconvolute the integrin-based and non-integrinbased cell binding, the adhesion assays were also run in the presence of EDTA (ethylenediaminetetraacetic acid), used to remove divalent cations by chelation. To assess the extent and the nature of cell attachment a series of static adhesion experiments were conducted using different cell lines in the presence of magnesium or EDTA. These were carried out on (a) polystyrene surfaces decorated with $\mathrm{Col}$ and Gel from solution (alone or in combination), (b) on 2D thin films of the same compositions, and (c) on 3D scaffolds before and after crosslinking with different EDC concentrations. This experimental approach, based on a systematic increase of the complexity of the system under study, aimed at providing a separate assessment of the influence on cell activity of the chemical identity and the availability/exposure of cell-recognition sequences alone (in coatings), of the influence of the bulk material properties and crosslinking treatments (in films) and of the effect of the complex 3D morphology on the nature and extent of cellsubstrate interactions (in scaffolds). Very rigorous washing routines have been applied to films and scaffolds after cell attachment to ensure the removal of non-specifically (weakly) bound cells to substrate in order to minimise the possible cell entrapment within material. 
B
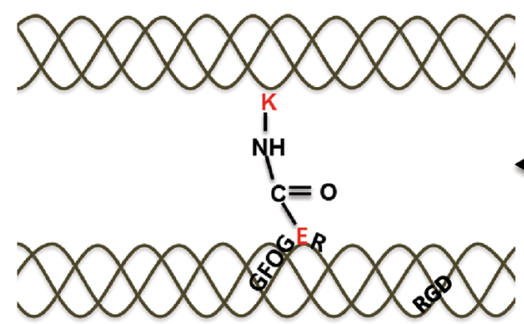

A

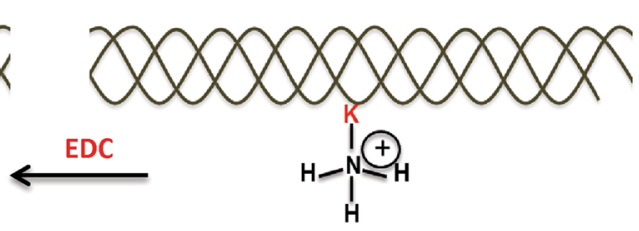

10000800008

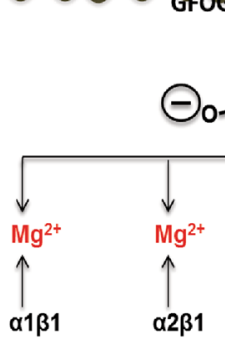

C

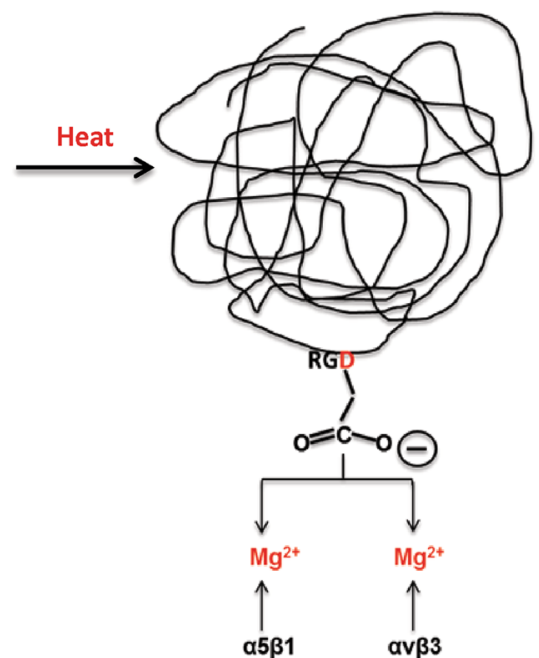

Fig. 1 Cellular interactions with $\mathrm{Col}$ and $\mathrm{Gel}$; effect of composition and EDC-mediated crosslinking. a Two adjacent Col helices are shown; in the first, a lysine amine-containing sidechain is shown, and in the second, the integrin-binding motif GFOGER is located, with its crucial glutamate acidic side chain protruding from the helix. The carboxylate anion is free to co-ordinate a $\mathrm{Mg}^{2+}$ ion that is bound to the integrin $\alpha$ subunit I domain, so that $\alpha 1 \beta 1, \alpha 2 \beta 1, \alpha 10 \beta 1$, or $\alpha 11 \beta 1$, whichever is expressed on the connective tissue cell surface, can secure cell binding to the matrix. $\mathbf{b}$ EDC promotes the cross-linking of the glutamate carboxylate group with the adjacent lysine amine group, forming an amide bond between adjacent $\mathrm{Col}$ helices. The glutamate sidechain can no longer interact with integrins. c Heating the Col unfolds the Col triple helix to yield a disordered, random coil structure, Gel. In the native helical form, the RGD motifs in Col (shown in a) are so constrained that they cannot bind integrin. In the unfolded Gel, RGD-containing strands are more flexible, and the aspartate sidechain is free to co-ordinate a $\mathrm{Mg}^{2+}$ ion bound in the $\beta$ subunit I-like domain of the integrin. Several integrins can bind RGD motifs in this way, including $\alpha 5 \beta 1$ and $\alpha \mathrm{V} \beta 3$, that are widely expressed in connective tissue cells. Thus, conversion of $\mathrm{Col}$ to form Gel by heating switches binding specificity from $\alpha 1 \beta 1, \alpha 2 \beta 1, \alpha 10 \beta 1$, or $\alpha 11 \beta 1$ to $\alpha 5 \beta 1$, and $\alpha \mathrm{V} \beta 3$

Fig. 2 Graphical representation of integrin-mediated adhesion on Col and Gel. Schematics of the integrin structure were adapted from [38]. The crystal structure of the integrin $\alpha 2$ I-domain binding to Col GFOGER was produced from pdb:1DZI and Cyclic RGD binding to the $\beta$-subunit I-likedomain was produced from pdb:1L5G

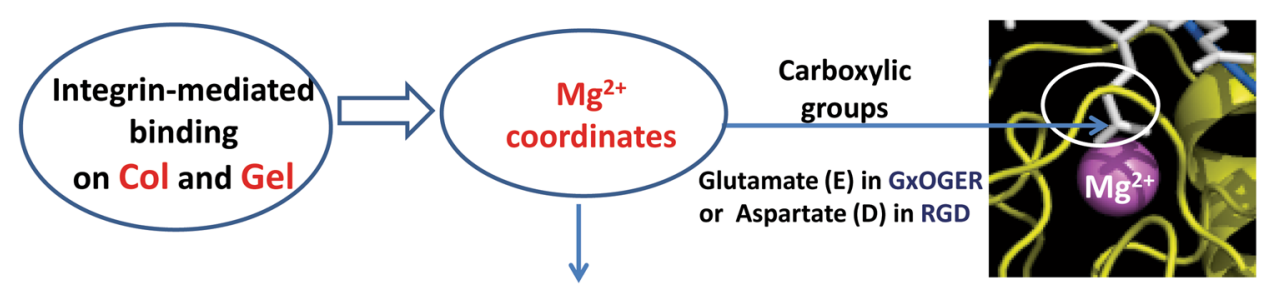

Integrin receptors
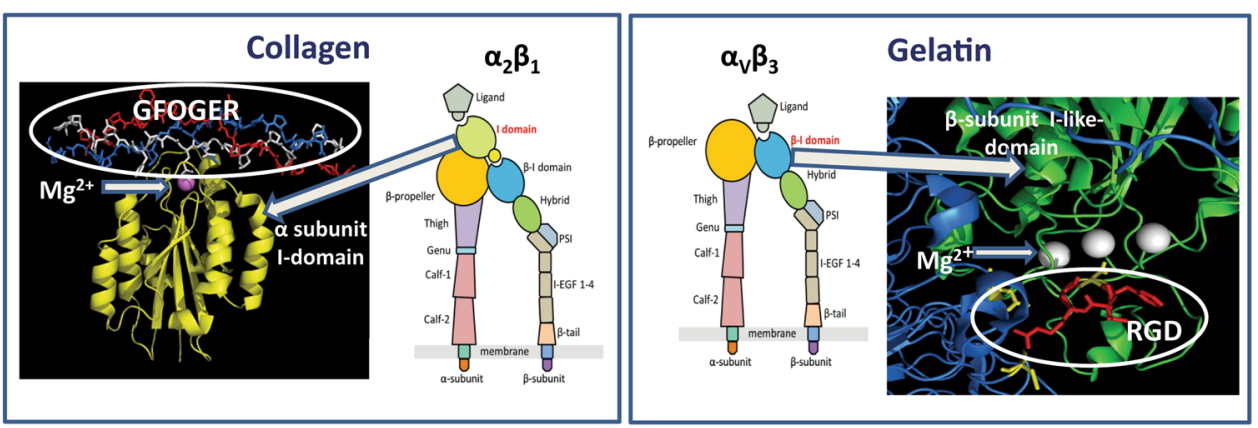

\section{Materials and methods}

\subsection{Materials}

\subsubsection{Cell lines}

HT1080 (fibroblasts from human sarcoma) cells were obtained from the European Collection of Animal Cell
Cultures, Porton Down, UK. C2C12 (mouse myoblast cell line) and $\mathrm{C} 2 \mathrm{C} 12-\alpha 2+$ (L3 cells), a stably transfected C2C12 with the human integrin $\alpha 2$ subunit, were a gift from Prof D. Gullberg, University of Bergen, Norway. Rugli (derived from a rat glioma) cells were a kind gift from Dr. J. Gavrilovic, University of East Anglia, Norwich, UK. 


\subsubsection{Materials}

Insoluble microfibrillar $\mathrm{Col}$ type I $(\mathrm{Col})$ derived from bovine Achilles tendon and Gel (type B from bovine skin, Gel) were purchased from Sigma-Aldrich Co. Ltd. UK. The control triple-helical Col-like peptide GPP10 was synthesized in Farndale lab as described previously [34, 39]. Acetic acid (2 M), EDC and NHS were purchased from Sigma-Aldrich Co. Ltd. UK. Dulbecco Modified Eagles Medium (DMEM), phosphate buffered saline (PBS), Foetal Calf Serum, penicillin, and streptomycin were purchased from Invitrogen Life Sciences (UK). Other commercially available reagents were all analytical grade.

\subsection{Tested substrates}

\subsubsection{Monolayer coated surfaces}

Col, Gel, and mixed $\mathrm{Col} / \mathrm{Gel}=50 / 50 \%$ wt compositions were coated on the surface of Immulon 2HB 96-well plates (Thermo Scientific) by incubating $100 \mu \mathrm{l} /$ well of $10 \mu \mathrm{g} / \mathrm{ml}$ solution in $10 \mathrm{mM}$ acetic acid containing the appropriate proteins over night at $4{ }^{\circ} \mathrm{C}$. Bovine serum albumin (BSA, Sigma) and triple-helical-like sequences GPP10 were plated in triplicate to act as nonspecific background adhesion controls.

\subsubsection{Films}

Protein films (Col, Gel, and $\mathrm{Col} / \mathrm{Gel}=50 / 50$ ) of $\sim 8 \mu \mathrm{m}$ thickness were prepared by drying the corresponding $0.5 \%$ $(\mathrm{w} / \mathrm{v})$ suspension $(\mathrm{Col}, \mathrm{Col}-\mathrm{Gel})$ or solution $(\mathrm{Gel})$ of protein in $0.05 \mathrm{M}$ acetic acid directly in Immulon $2 \mathrm{HB}$ plates (Thermo Scientific). Suspensions were prepared by swelling Col overnight at $4{ }^{\circ} \mathrm{C}$ and then homogenising on ice for 30 min at $13500 \mathrm{rpm}$ using an Ultra-Turrax VD125 (VWR International Ltd., UK). Air bubbles were removed from the suspension by centrifuging at $2500 \mathrm{rpm}$ for $5 \mathrm{~min}$ (Hermle Z300, Labortechnik, Germany). Gel solution was prepared at $37-45^{\circ} \mathrm{C}$ with stirring for $1 \mathrm{~h}$ and then cooled to room temperature. To produce Col-Gel (50/50\%wt.) composition, equal volumes of $\mathrm{Col}$ suspension and Gel solution were mixed, homogenised for $15 \mathrm{~min}$ and then centrifuged as described above.

\subsubsection{Scaffolds}

Protein scaffolds ( $\mathrm{Col}, \mathrm{Gel}$ and $\mathrm{Col} / \mathrm{Gel}=50 / 50)$ were obtained by freeze-drying of $1 \%(\mathrm{w} / \mathrm{v})$ suspensions $(\mathrm{Col}$, Col-Gel) or $1 \%(\mathrm{w} / \mathrm{v})$ Gel solutions in $0.05 \mathrm{M}$ acetic, prepared as described above. These suspensions/solution were poured into silicone rubber trays (Lakeland, UK) and lyophilised in a VirTis adVantage bench-top freeze-drier
(Biopharma Process Systems, UK) using a cycle adapted from our previous work $[14,15,30]$. Temperature of $-26^{\circ}$ $\mathrm{C}$ for freezing and $0^{\circ} \mathrm{C}$ for drying under vacuum (less than 100 mTorr) were applied.

\subsection{Crosslinking}

Films and scaffolds were cross-linked (XL) with carbodiimide (EDC) in combination with succinimide (NHS). An EDC concentration of $11.5 \mathrm{mg} / \mathrm{ml}$ and molar ratio EDC/ $\mathrm{NHS} / \mathrm{COO}^{-}(\mathrm{Col})=5 / 2 / 1$, was taken as standard $(100 \%)$ and was varied from 1 to $200 \%$ of this concentration. After reaction in the corresponding EDC/NHS solution for $2 \mathrm{~h}$ at room temperature, the films and the scaffolds were washed thoroughly in deionised water $(15 \min \times 5)$ and then films were dried in a fume hood while scaffolds were refrozen and re-lyophilized using the previous freeze-drying cycle.

\subsection{Cell adhesion and spreading}

Cell adhesion in the presence of $\mathrm{Mg}^{2+}$ (total) and EDTA (non-specific) was assessed calorimetrically through the measurement of lactate dehydrogenase (LDH) activity release from adhered cells into the media.

All cell lines were maintained in a humidified incubator with $5 \% \mathrm{CO}_{2}$ at $37{ }^{\circ} \mathrm{C}$ in DMEM containing $10 \%$ fetal bovine serum and $1 \%$ streptavidin/penicillin. Prior to cell adhesion experiments, cells were detached from the cell culture flasks with $0.05 \%$ trypsin $/ 0.02 \%$ EDTA (GE Healthcare), washed and re-suspended in serum free DMEM.

\subsubsection{Cells adhesion on surfaces and films}

Non-specific adsorption to the surfaces/films was blocked with $200 \mu \mathrm{l}$ per well of bovine serum albumin (BSA, $5 \%$ (w/v) in PBS) for $60 \mathrm{~min}$, and then wells were washed three times with $200 \mu \mathrm{l}$ of PBS. $100 \mu \mathrm{l}$ of cell suspension at different concentrations (from 0.5 to $7 \times 10^{5}$ cells $/ \mathrm{ml}$ in serum free DMEM) containing either $5 \mathrm{mM} \mathrm{Mg}^{2+}$ or $5 \mathrm{mM}$ EDTA, were added to the wells and allowed to attach at room temperature for $60 \mathrm{~min}$. The wells were washed with PBS $(200 \mu \mathrm{l} \times 3)$ to remove loosely bound cells and then $50 \mu \mathrm{l}$ of lysis buffer containing $2 \%$ v/v Triton X-100 in distilled water was added for $90 \mathrm{~min}$ at room temperature. Subsequently $50 \mu \mathrm{l}$ of $\mathrm{LDH}$ detection substrate (cytotoxicity detection kit (LDH), Roche, Cat. No 11644 793001) prepared according manufacture instruction, was added and left until color had developed (from 10 to $30 \mathrm{~min}$ ). The absorbance was read at $490 \mathrm{~nm}\left(\mathrm{~A}_{490}\right)$ using a Fluostar Optima plate reader (BMG Labtech). Background adhesion was determined on BSA and GPP10 coated plates. Cell adhesion 
assays were performed in triplicate and values are reported as means \pm standard deviations.

Adhesion on films was carried out in the presence and absence of cyclo Arg-Gly-Asp-D-Phe-Val, (cRGD) (Calbiochem, Nottingham, UK, Cat No182015) following the same protocol as above except that cell suspensions containing $5 \mathrm{mM} \mathrm{Mg}^{2+}$ and $10 \mathrm{mM}$ cRGD were pre incubated for 15-20 min prior to seeding.

For quantitative analysis of adhesion linear regression calibration curves were constructed from the OD (optical density) vs. initial cell concentration for each experiment. The calibration was obtained by taking $500 \mu$ l aliquot of cell suspension at a known cell density and then subsequently serially diluting this from 32 to 64 times depending on the cell density. These known cell number suspensions were centrifuged and the cell pellet lysed by adding $500 \mu \mathrm{l}$ of buffer containing $2 \% \mathrm{v} / \mathrm{v}$ Triton X-100 in distilled water for $90 \mathrm{~min}$ at room temperature. The cell lysate was vortexed and then and $50 \mu \mathrm{l}$ aliquots of each solution were pipetted in triplicate on to the same plate corresponding to the cell attachment analysis. After that $50 \mu \mathrm{l}$ of $\mathrm{LDH}$ detection substrate were added to the calibration series at the same time as to the substrates under study and left until color had developed (from 10 to $30 \mathrm{~min}$ ). The absorbance of this series was read under the same conditions/time as on coated wells.

\subsubsection{Cell adhesion on scaffolds}

Scaffold discs were cut from the central part of scaffold sheets using a sterile $8 \mathrm{~mm}$ biopsy punch $(8 \mathrm{~mm}$ (d) x 2-3 $\mathrm{mm}(\mathrm{h}), 1.9-2.3 \mathrm{mg}$ ) and incubated (6 replicas for each composition/XL condition) with $500 \mu \mathrm{l}$ of PBS for $1 \mathrm{~h}$ in 24-well tissue culture plates (Thermo Scientific). The scaffolds were removed, gently pressed between sheets of filter paper and placed into wells with $500 \mu \mathrm{l}$ of cell suspension (concentrations from 1 to $5 \times 10^{5}$ cells $/ \mathrm{ml}$ ) in serum free DMEM, containing either $5 \mathrm{mM} \mathrm{Mg}^{2+}$ or $5 \mathrm{mM}$ EDTA. These were incubated for $60 \mathrm{~min}$ at room temperature to allow cell attachment. The scaffolds were removed, placed in $7 \mathrm{ml}$ tubes and washed with $5 \mathrm{ml}$ of serum free DMEM, containing either $5 \mathrm{mM} \mathrm{Mg}^{2+}$ or $5 \mathrm{mM}$ EDTA according to the attachment conditions. Tubes were put on a roller for 15 min and this procedure was repeated 5 times to ensure the complete removal of the media with non-attached or loosely bound cells from the scaffold porous structure. $500 \mu \mathrm{l}$ of lysis buffer containing $2 \% \mathrm{v} / \mathrm{v}$ Triton X-100 in distilled water was added for $90 \mathrm{~min}$ at room temperature. $50 \mu \mathrm{l}$ aliquots of lysis solution was pipetted in triplicate into 96 well plate and $50 \mu \mathrm{l}$ of LDH detection substrate, prepared according manufacture instruction, was added and incubated until color had developed (from 10 to $30 \mathrm{~min}$ ). The absorbance was read at $490 \mathrm{~nm}\left(\mathrm{~A}_{490}\right)$ using a Fluostar
Optima plate reader (BMG Labtech). For quantitate evaluation of adhesion each experiment was carried out in presence of a calibration series (as described above). Cell adhesion on scaffolds was performed in triplicate and values are reported as means \pm standard deviations.

\subsubsection{Cell spreading tests}

For spreading analysis, $100 \mu$ l of cell suspension at $1 \times 10^{5}$ cells/ml containing either $5 \mathrm{mM} \mathrm{Mg}^{2+}$ or $5 \mathrm{mM}$ EDTA in serum free DMEM were added to BSA blocked surfaces for $90 \mathrm{~min}$ at $37^{\circ} \mathrm{C} / 5 \% \mathrm{CO}_{2}$. The cells were fixed by the addition of $9 \mu \mathrm{l}$ of $37 \%$ (w/v) formaldehyde (final concentration $3.7 \%$ ) directly to the cell media for $20 \mathrm{~min}$ at room temperature. The samples were washed $3 \times 200 \mu \mathrm{l}$ PBS then viewed using a LEICA DMI6000CS phase contrast microscope fitted with a LEICA DFC340FX camera. Assays were performed in triplicate.

Cell spreading (percentage of spread cells versus total number of cells) was determined by analyzing 12 images per condition and applying the following equation (1):

$$
\begin{aligned}
& \% \text { Spread Cells (per image })= \\
& \frac{\# \text { Spread Cells }}{\text { \# Total Cells }(\text { Spread }+ \text { Non }- \text { Spread Cells })}
\end{aligned}
$$

The error was determined as the standard deviation between spreading \% values calculated from at least three separate experiments, each with triplicate measurements for each experimental condition.

\subsection{Statistical analysis}

Data are expressed as the mean \pm standard deviation (SD). Statistical analysis was performed using the two population Student's $t$-test assuming unequal variances. The significant level (*) was set as $P \leq 0.05$. (**) indicates $P \leq 0.01$; (***) indicates $P \leq 0.001$ and $(* * * *)$ indicates $P \leq 0.0001$.

\section{Results}

\subsection{Cell adhesion and spreading on monolayer coated surfaces}

Studies were first performed on monolayer coatings of the molecules of interest applied to a polystyrene tissue culture plastic surface. Since only single molecule layers were used, no crosslinking was applied to the molecular surfaces. Testing cell interactions when the material is presented in this form means that the surface is two-dimensional and that bulk mechanical effects such as different stiffnesses are eliminated. 
Cell lines selected in this work allow a comparison to be made between the interaction of $\mathrm{Col}$ and Gel-based compositions with cells that express Col-binding integrins (HT1080 and L3 expressing $\alpha 2 \beta 1$, and Rugli expressing $\alpha 1 \beta 1$ ) and a parent cell line $\mathrm{C} 2 \mathrm{C} 12$, which only possess Gel-binding integrins, $\alpha v \beta 3$ and $\alpha 5 \beta 1$. BSA, frequently used to block any active sites on well surfaces, preventing cells from adhesion to any uncoated plastic, and GPP10 peptide, which adopts a Col-like triple helix [40, 41], but lacks any cell recognition motifs were used as negative control.

\subsubsection{Adhesion of different cell lines to monolayer coated surfaces}

All cell adhesion tests on coatings were carried out in the presence of calibration solutions (as described in 2.4.1) in the interval of the initial cell concentrations varying from 0.5 to $8 \times 10^{5}$ cells $/ \mathrm{ml}$ in order to establish the dependence of adhesion percentages on the seeded density. Results revealed that adhesion values, calculated using calibration curves, increased linearly with the seeded cell concentration, in a range from 0.5 to $1.5-2 \times 10^{5}$ cells $/ \mathrm{ml}$, for all compositions studied (Fig. 3). At higher initial cell concentrations this linearity was gradually altered, reaching saturation at values higher that $4-5 \times 10^{5}$ cells $/ \mathrm{ml}$ (data not shown).

Adhesion profiles of $\mathrm{Mg}^{2+}$-dependent (all adhesion), non-specific (EDTA) and only integrin dependent cell attachments on $\mathrm{Col}$ and Gel-based substrates are displayed in Fig. 4. These profiles show the cell adhesion percentage values in the linear concentration dependence interval $(1 \times$ $10^{5}$ cells/ml) for all cell lines. It can be observed that for cell lines expressing Col-binding integrins (HT1080, Rugli and L3; Fig. 4a, b, d) all adhesion is integrin-dependent. For these three cell types, the addition of Gel to Col influences adhesion pattern in the same way: adhesion values decrease with the increase of Gel content. This is probably due to a decrease in the density of available integrin-binding sites (triple-helical GFOGER sequences) with the rise of Gel.
In a case of the $\mathrm{C} 2 \mathrm{C} 12$ parent cells (expressing only Gelrecognition receptors) no adhesion was observed on Col coatings. Surprisingly, these cells have also not attached to Gel-containing samples (50\% and $100 \%$ Gel, Fig. 4c) in spite of the fact that both compositions possess RGD recognition sequences likely to be revealed in the unfolded Col that are directed to $\alpha v \beta 3$ and $\alpha 5 \beta 1$ receptors expressed in $\mathrm{C} 2 \mathrm{C} 12$. This result suggests that cells do not identify RGD adhesion cues in Gel-based coatings. It seems likely that in creating a monolayer coating of Gel, the conformation of the flat RGD motif is altered, changing its exposure to cell recognition receptors and making it inactive.

Adhesion percentages summarised in Table 1 indicate that on pure Col coatings the adhesion is higher for cells expressing $\alpha 2 \beta 1$ integrin (HT1080 and L3) than for Rugli, which express $\alpha 1 \beta 1$. These results point to differences in affinity of Col cell-recognition sequences towards these two Col-binding receptors. On mixed compositions $(50 \%$ of Gel) and on pure Gel samples, the values were higher for L3 cells (expressing $\mathrm{Col}$ and Gel-binding receptors) than for cells possessing only Col-binding integrins (HT1080 and Rugli).

\subsubsection{Spreading of all cell lines on monolayer coated surfaces}

Images of the cell spreading of all cell lines in presence of $\mathrm{Mg}^{2+}$ are displayed in Fig. 5a. In EDTA containing media, no spreading was detected for any cell line on any surface (data not shown), which is in concordance with the results of adhesion experiments where no attachment was observed for cells incubated in the presence of EDTA.

Results in Fig. 5a show that HT1080, Rugli and L3 cells, expressing Col-binding integrins, are all spread in a similar way on Col-based samples. C2C12 cells, possessing only Gel recognition receptors, were all round-shaped (not spread) on any coatings including pure Gel composition.

Quantification of spreading capacity for cells expressing Col-binding receptors (Fig. 5c) showed a very high level of spreading (between 95 and $90 \%$ ) on Col coatings, being
Fig. 3 Magnesium dependent adhesion (percentage of adhesion) of HT1080 (left panel) and Rugli (right panel) cells on surfaces of different compositions as a function of initial cell concentration
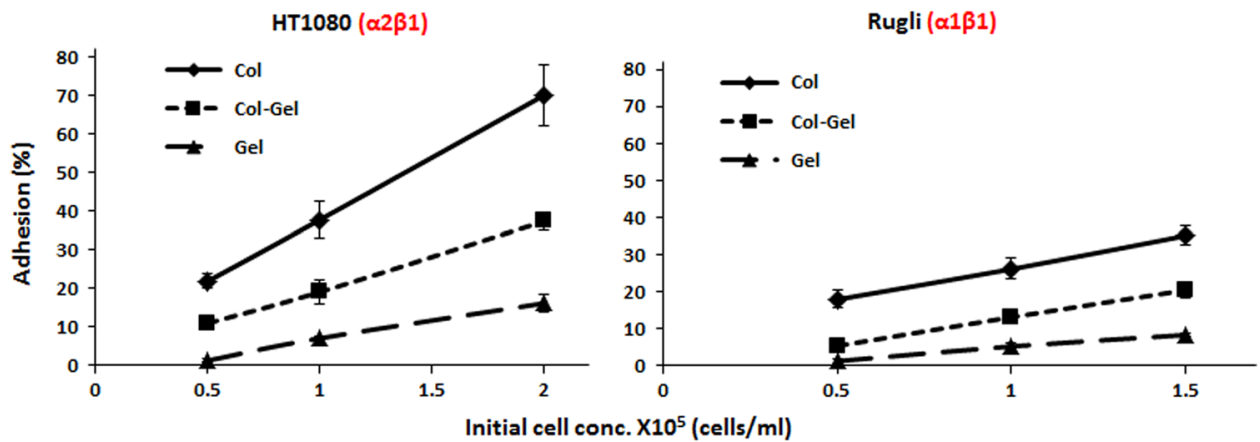


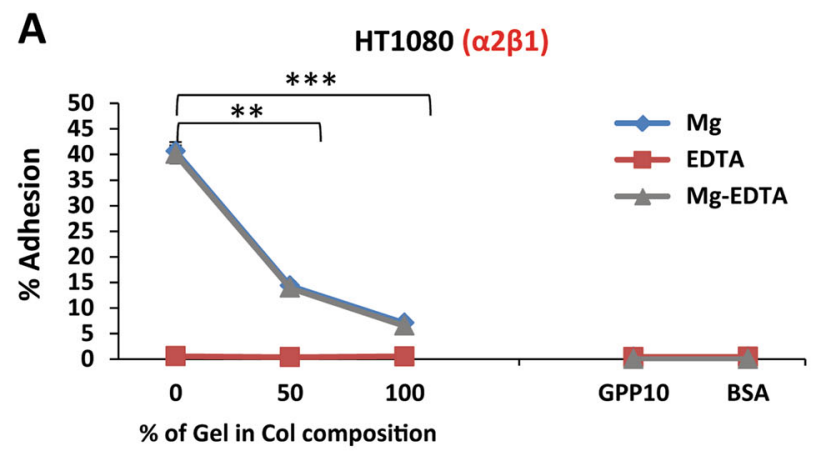

C $\mathrm{C} 2 \mathrm{C12}(\alpha \mathrm{v} \beta 3, \alpha 5 \beta 1)$

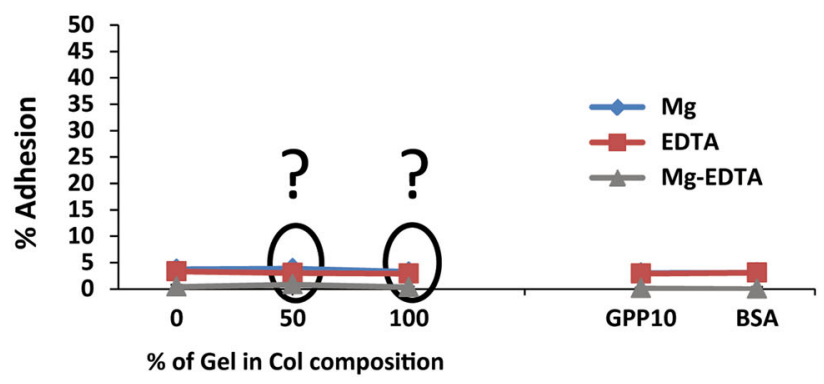

Fig. 4 Magnesium-dependent, non-specific (EDTA) and integrin mediated (Mg-EDTA) adhesion profiles of different cell lines as detailed in panels A to D, below, on treated surfaces. Initial cell

Table 1 Adhesion percentage on surfaces of cell lines expressing Col-binding integrins

\begin{tabular}{|c|c|c|c|}
\hline \multicolumn{4}{|c|}{ Adhesion $(\%)$} \\
\hline \multicolumn{4}{|c|}{ Cell concentration $1 \times 10^{5}$ cells $/ \mathrm{ml}$} \\
\hline & \multicolumn{3}{|l|}{ Cell line } \\
\hline & HT1080 & Rugli & L3 \\
\hline Col & $37.8 \pm 4.6$ & $26.2 \pm 2.8$ & $42.6 \pm 3.0$ \\
\hline Col-Gel & $11.0 \pm 1.1$ & $19.1 \pm 3.1$ & $21.1 \pm 2.3$ \\
\hline Gel & $7.1 \pm 0.7$ & $5.3 \pm 0.7$ & $15.2 \pm 1.3$ \\
\hline
\end{tabular}

Note: Results are expressed as mean values of three parallel measurements \pm standard errors

lower on mixed Col-Gel samples for L3 (82\%) and especially for Rugli cells (77\%). Statistical analysis confirmed significant differences between spreading values of HT1080, L3 and Rugli cells on Col and Gel coatings and also between pure $\mathrm{Col}$ and samples containing $50 \%$ of Gel in case of L3 and Rugli cells.

\subsection{Cell adhesion on thin films}

Having observed the behaviour of the cells on monolayer surfaces, we next applied cells to thin films of the molecules of interest. In this form, the materials presented to the cells
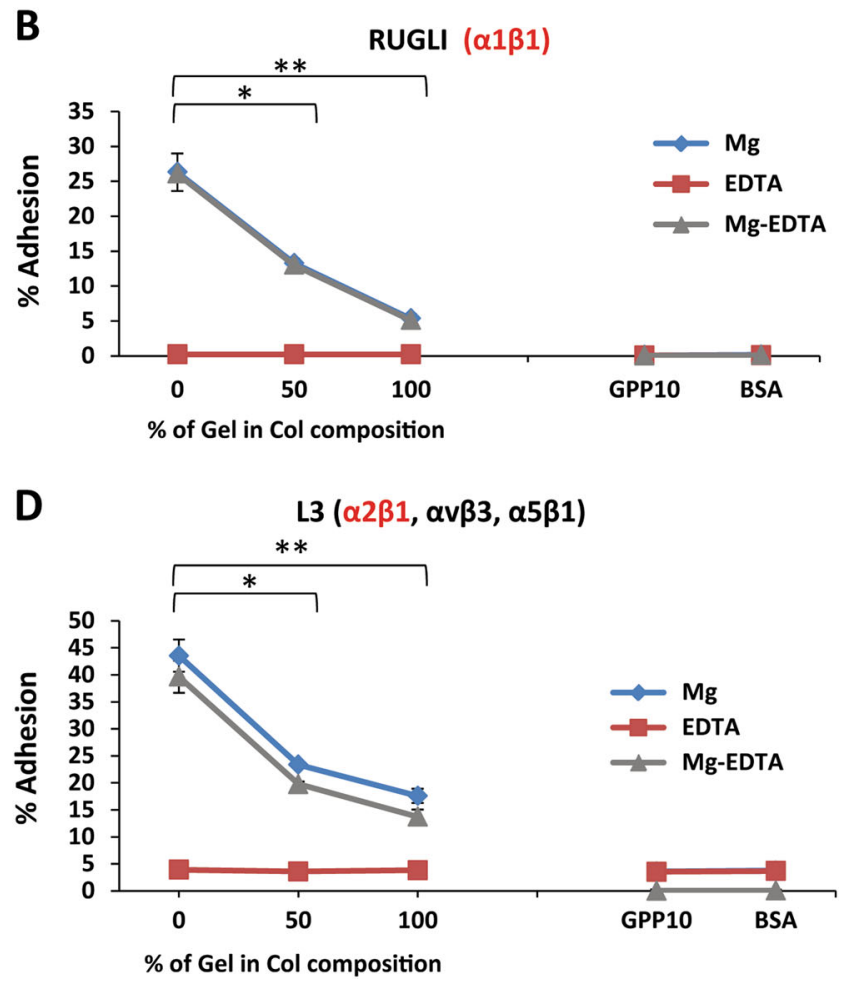

concentration $1 \times 10^{5}$ cells $/ \mathrm{ml}$. * indicates $P \leq 0.05$, **indicates $P \leq$ 0.01 and $* * *$ indicates $P \leq 0.001$ ( $t$-test) against different percentage of $\mathrm{Gel}$ in Col composition values

are still 2D, but are thick enough to exhibit stiffnesses representative of the bulk materials and molecular conformations unaffected by the underlying substrate. Furthermore, in thin films, the chemical identity and the availability of cell-recognition sequences may be changed not only by composition, but also by alteration in a crosslinking status. Studies on films were carried out in presence and absence of cRGD, a selective antagonist of $\alpha_{\nu} \beta_{3}$ and $\alpha_{v} \beta_{5}$ integrins, to establish (a) whether the RGD motif is in a right configuration for cell recognition and (b) if the attachment of $\mathrm{C} 2 \mathrm{C} 12$ parent and $\alpha 2$-positive, L3, cells were via RGD binding sequences. For comparison, adhesion of HT1080 cells was also tested on films in presence and absence of cRGD peptide. Fig. 6 shows the adhesion percentages of all cell lines on films with different composition and crosslinking conditions. No results are presented on Non-XL Col-Gel and Gel samples as these compositions were too unstable to resist incubation without partial dissolution and/or detachment from the well surfaces, which may alter the values of cell adhesion.

The results displayed in Fig. 6a show that for HT1080 cells, $\mathrm{Mg}^{2+}$-dependent cell adhesion on Col-based scaffold (with and without $50 \%$ of Gel) was due to binding of $\alpha 2 \beta 1$ to GxOGER sequences of Col. This process, as expected, was not affected by the presence of the cRGD. No adhesion of HT1080 was detected on Gel films due to the absence of 


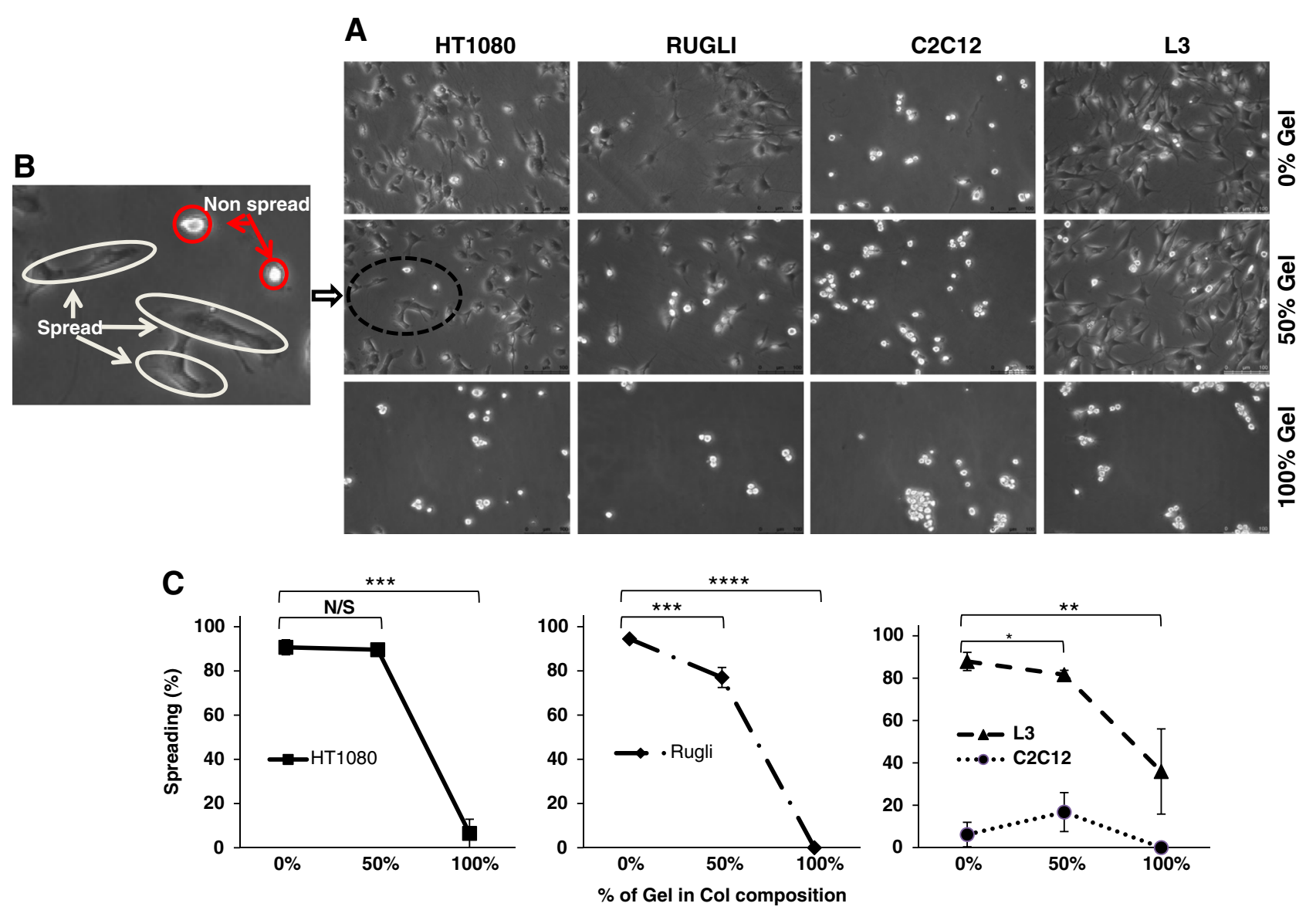

Fig. 5 Images of cells that are exposed to Col, Col-Gel, and Gel surfaces in the presence of $\mathrm{Mg}^{2+}$ a. The enlarged area $\mathbf{b}$ shows how cells are categorising as spread (large, phase contrast dark) or non-

RGD-recognition receptors in this cell line. Conversely, the parent $\mathrm{C} 2 \mathrm{C} 12$ cells do not adhere to pure $\mathrm{Col}$ films but do show the integrin-mediated attachment to both pure Gel and to the mixed Col-Gel films (Fig. 6b) suggesting that the exposure of RGD motif to cells in Gel-containing films is recognisable by cell surface integrins (unlike Gel-coated surfaces). Moreover, C2C12 attachment to Gel-containing films was completely blocked by the presence of the RGD antagonist, cRGD (Fig. 6b), which confirms that RGD ligand is responsible for cell attachment via $\alpha v \beta 3$ and $\alpha 5 \beta 1$ integrins. For the L3 cells, which possess $\alpha 2 \beta 1, \alpha \mathrm{V} \beta 3$, and $\alpha 5 \beta 1$ integrins, the detected $\mathrm{Mg}^{2+}$-dependent adhesion on pure Col and Col-Gel was similar to HT1080 and can be attributed almost entirely to binding of $\alpha 2 \beta 1$ to GxOGER sequences as binding was largely insensitive to the presence of the cRGD (Fig. 6c). On pure Gel films, the $\mathrm{Mg}^{2+}$-promoted adhesion was observed for both $\mathrm{L} 3$ and $\mathrm{C} 2 \mathrm{C} 12$ cells because of interaction of $\alpha v \beta 3$ and $\alpha 5 \beta 1$ with RGD ligands. The attachment of both cell lines was abolished by the presence of cRGD, with no difference in the response to EDTA-inhibited samples. spread (small, phase contrast bright). Quantification is the percentage of cells that are spread c, illustrating the effect of composition on the level of spreading of attached cells

Analysis of the influence of crosslinking on integrinpromoted cell attachment to films showed that adhesion decreases with increase of EDC concentration for all cell lines. This suggests that EDC-mediated treatment may abolish cell adhesion by consuming cell binding sites on Col and Gel-based films.

\subsection{Cell adhesion on 3D scaffolds}

Finally, after considering monolayer coated surfaces and thin films, we applied cells to 3D scaffolds made from the molecules of interest. In this form, the scaffold struts are expected to have similar mechanical properties and molecular conformations as the thin films, but with the added complexity of a 3D porous structure. Cell attachment experiments on scaffolds addressed the influence of both composition and crosslinking (from non-XL to $100 \%$ EDCtreated Col-based samples) on the cell interaction with highly porous $3 \mathrm{D}$ substrates.

The effect of composition may be observed in Fig. 7, where adhesion profiles of $100 \%$ EDC treated pure Col 

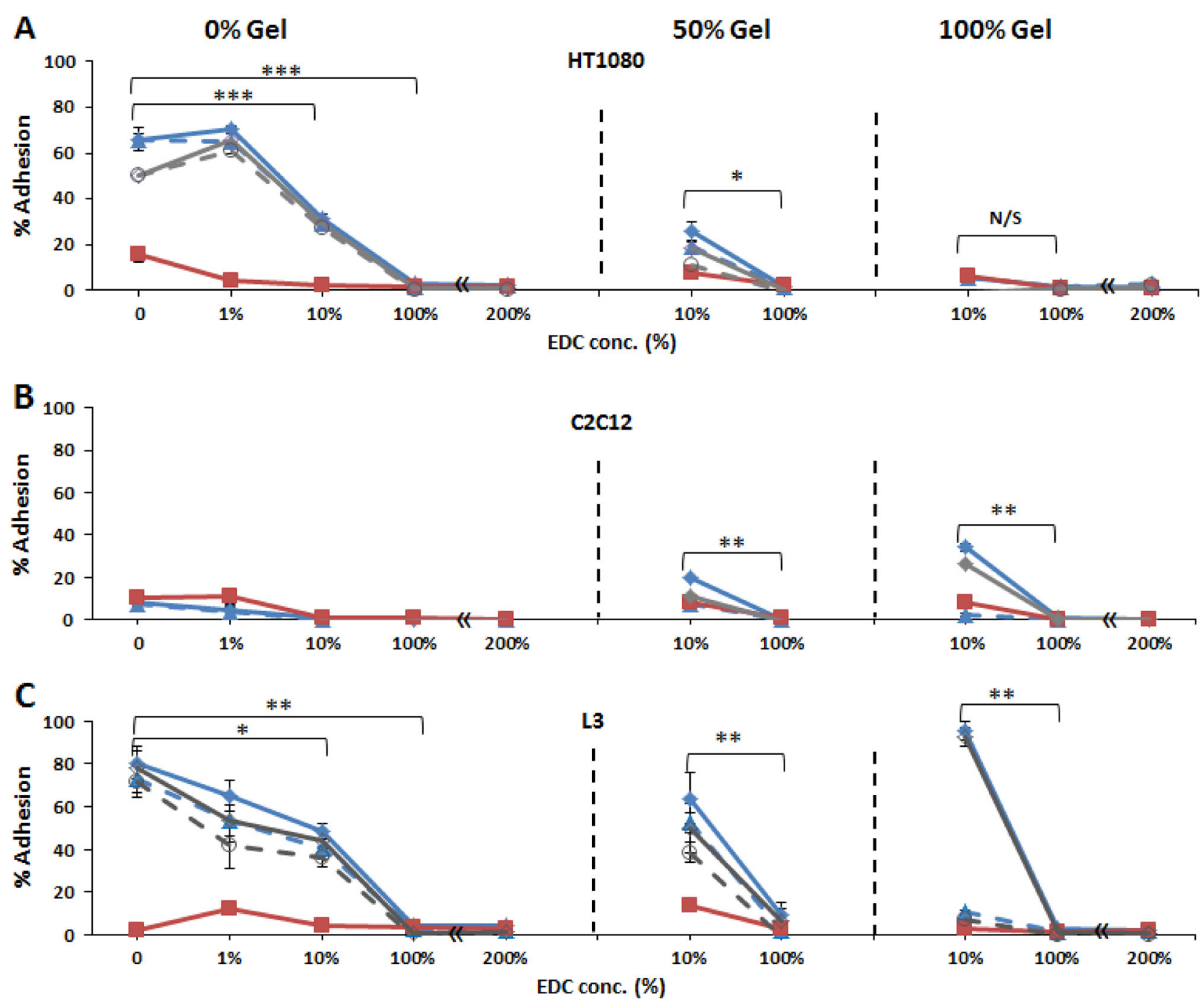

Fig. 6 Adhesion (\%) of HT1080 a, C2C12 b and L3 c cells on films with different composition and crosslinked status. Initial cell concentration $1 \times 10^{5}$ cells $/ \mathrm{ml}$. Full circle $(\bullet)$ with solid line shows $\mathrm{Mg}^{2+}$ dependent cell adhesion; triangle $(\Delta)$ with dashed line shows $\mathrm{Mg}^{2+}$ dependent cell adhesion in presence of cRGD; full square (๘) with

scaffolds with and without addition of different percentages of Gel are displayed. A common feature of all adhesion patterns on scaffolds is a significant level of non-integrinmediated interaction (in presence of EDTA) between cells and 3D substrates. This is markedly different from the results on monolayer coated surfaces and thin films where non-specific adhesion is consistently low. Mg-dependent adhesion depends on both composition and cell line. Cell adhesion decreases with Gel content for both HT1080 and Rugli cells (Fig. 7a, b), is comparable on Col and Gel scaffolds for L3 (Fig. 7d) and is greatest on Gel scaffolds for $\mathrm{C} 2 \mathrm{C} 12$ (Fig. $7 \mathrm{c}$ ). In the case of $\mathrm{L} 3$ cells, $\mathrm{Mg}^{2+}$-dependent adhesion is significantly higher than non-specific (EDTA) for pure Col scaffolds $(P \leq 0.01)$. In contrast, solid line shows EDTA-dependent adhesion; empty circle (O) with solid line shows only integrin-dependent adhesion ( $\mathrm{Mg}^{2+}-$ EDTA) and empty circle (O) with dashed line shows only integrin-dependent adhesion $\left(\mathrm{Mg}^{2+}-\mathrm{EDTA}\right)$ in presence of cRGD. Composition of films and cell line is indicated above each panel.

$\mathrm{Mg}^{2+}$-mediated adhesion of $\mathrm{C} 2 \mathrm{C} 12$ parent cells was significantly higher than EDTA-promoted $(P \leq 0.001)$ for Gel samples as a results of the presence of Gel-binding receptors in $\mathrm{C} 2 \mathrm{C} 12$.

Comparison of the effect of crosslinking on adhesion values of HT1080 and Rugli cells on Col scaffolds (Fig. 8) shows that both the total adhesion $\left(\mathrm{Mg}^{2+}\right.$ dependent $)$ and the non-specific, non-integrin promoted (in the presence of EDTA) adhesion significantly increase with crosslinking. However, the integrin-mediated interactions (lines inside dashed circles on Fig. 8) decrease with the increase of crosslinking (in agreement with the results obtained on films) suggesting that EDC crosslinking diminishes the availability of cell-binding ligands on both 2D and 3D substrates. 
Fig. 7 Adhesion (\%) of HT1080 a, Rugli b, C2C12 c and L3 d cells on $100 \%$ EDC-XL scaffolds of different compositions. Initial cell concentration $5 \times 10^{5}$ cells $/ \mathrm{ml}$. $\mathrm{N} / \mathrm{S}$ indicates no significant differences between values $(P \geq 0.05)$
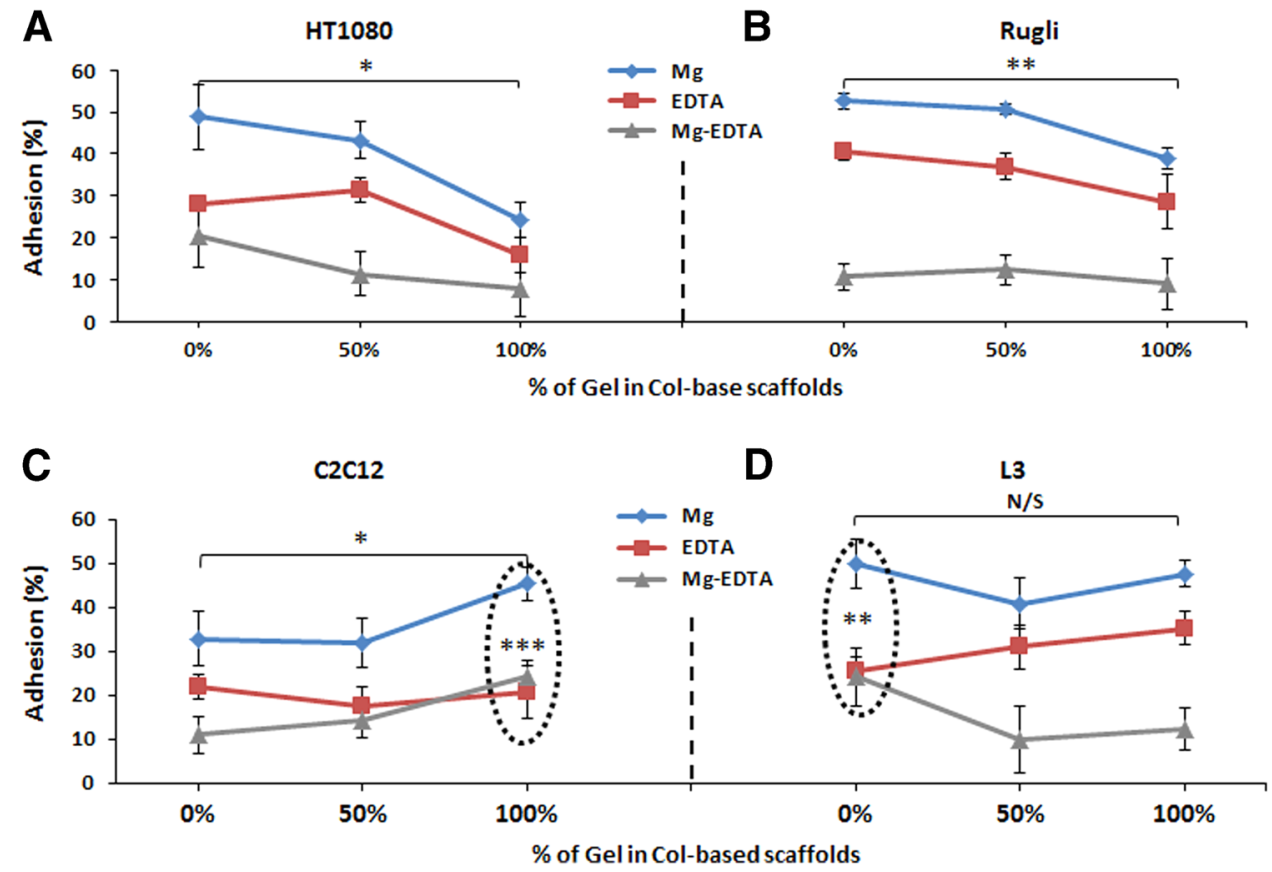

\section{Discussion}

Cell adhesion is usually the first step in the biological assessment of biomaterials aimed at TE applications. Adhesion studies were carried out on Col and Gel-based substrates with different 2D and 3D architecture in order to establish the influence of composition and crosslinking treatment on the extent and nature of attachment of cell lines expressing different matrix-binding receptors. Samples were studied in the form of monolayer coated surfaces, thin films, and scaffolds to assess the effects of bulk properties and of $2 \mathrm{D}$ and $3 \mathrm{D}$ presentation.

\subsection{Adhesion and spreading on monolayer coated surfaces}

Adhesion and spreading on monolayer coated surfaces prepared with the same protein content as films and scaffolds provide the possibility of creating the same assembly of integrin recognition sequences as in the scaffold struts. This in turn allows the influence of the chemical identity of ligands and availability/accessibility of these cell binding motifs on cell-substrate interactions to be assessed without the interferences from physical properties and/or the complex 3D architecture.

Adhesion profiles for cells on surfaces revealed that the addition of Gel to Col composition caused a decrease in the ability of cell lines expressing Col-binding integrins to attach to the substrate. This may be explained by a decrease in the availability of GxOGER and an increase in the availability of RGD when the base protein layer is changed from Col to Gel. The decrease in GxOGER ligand density consequently diminishes the number of cell-recognition cues required for cell attachment via Col-binding receptors ( $\alpha 2 \beta 1$ and $\alpha 1 \beta 1)$. Adhesion on pure Col coatings was higher for HT1080 and L3 cells, both expressing $\alpha 2 \beta 1$ integrin, than for the Rugli cell line, which expresses $\alpha 1 \beta 1$ receptors. This may be attributed to differences in the affinity of Col GxOGER ligands towards $\alpha 2 \beta 1$ and $\alpha 1 \beta 1$ integrins, reported in [42]. The lack of adhesion of $\mathrm{C} 2 \mathrm{C} 12$ parent cells to Gel surfaces may be the result of configurational changes in RGD sequences, most probably due to their interaction with surfaces. It seems that a flattened topology of this linear motif on the plastic substrate induces some kind of bond formation between RGD and the surface, which may alter the correct exposure of this motif to cell receptors, suggested to require RGD presentation in a flexible loop [43]. This may explain the lack of attachment of $\mathrm{C} 2 \mathrm{C} 12$ on Gel surfaces. This is an important potential limitation of the use of monolayer surface coatings in cell binding assays.

Spreading assays were performed to assess the ability of bound cells to spread as a result of the correct stimulation of certain signaling pathways after attachment. This provides the alternative way of evaluating the "quality" of adhesion: be it integrin-mediated (leading to spreading) or non-specific (no spreading, no further cell activity). These assays were performed in serum-free media to prevent cell adhesion to serum containing proteins such as vitronectin and fibronectin, which may alter spreading patterns. The evaluation of spreading was based on the analysis of cell shape (extended vs. round-shaped) according to a traditional view 
Fig. 8 Effect of crosslinking on the adhesion of cells expressing Col-binding integrins (HT1080 and Rugli) on Col scaffolds. $\mathrm{Mg}$ indicates total adhesion, EDTA indicates non-specific cellscaffold interactions and $\mathrm{Mg}$ EDTA shows only integrinmediated adhesion. Initial cell concentration $5 \times 10^{5}$ cells $/ \mathrm{ml}$

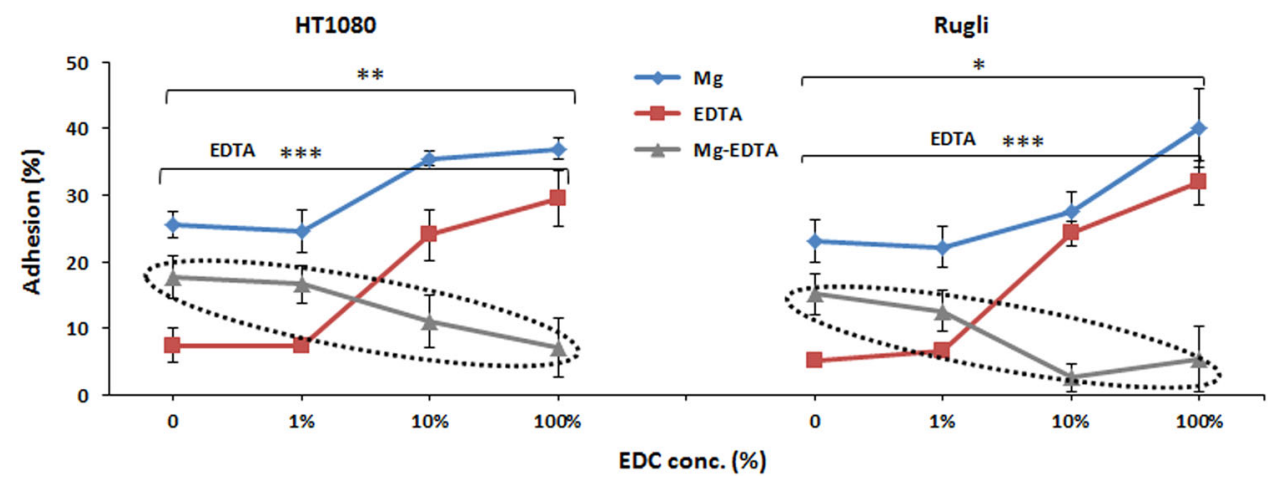

of cell spreading. The overall cellular surface coverage was not taken into account as it reflects more the degree of cell attachment than cell spreading ability. Results confirmed the importance of integrin-specific interactions on cell activity: spreading of cells expressing Col-binding receptors (HT1080, Rugli and L3) was very high on Col-based surfaces, which points to the correct stimulation of cell attachment mechanisms in these systems. Lack of spreading of $\mathrm{C} 2 \mathrm{C} 12$ cells on Gel surfaces (only round cells) is in agreement with the absence of integrin mediated adhesion on Gel samples.

\subsection{Adhesion on thin films}

Adhesion tests on films were performed to assess the cellscale properties of 3D matrices without interference from the complex 3D morphology of a scaffold. In thin films, both composition and crosslinking were systematically modified to evaluate the impact of these changes on the biological activity of the resultant systems. All films were of $\sim 8 \mu \mathrm{m}$ thickness, which guaranteed the separation (for several layers) of cell-recognition ligands from the plate surface in order to ensure that the conformation of cellbinding sequences exposed to cells might not be compromised by their interactions with the surface. As such we anticipated the appropriate exposure of both Col and, especially, Gel-binding ligands to cells. The response of C2C12 myoblasts, $\alpha 2$ positive C2C12 (L3), and HT1080 cells on films containing $\mathrm{Col}, \mathrm{Gel}$, and a combination of both showed strong influence on cell adhesion of the alteration in the availability of binding sites, induced by changes in composition and the extent of crosslinking. For Col-based compositions, the trends in the adhesion results on films are in agreement with the trends found on the corresponding surfaces for all the cell lines studied. On mixed Col-Gel films, it seems that only Col-promoted cell attachment (due to interactions of $\alpha 2 \beta 1$ with GxOGER) is happening for $\mathrm{C} 2 \mathrm{C} 12-\alpha 2+$ cells as attachment was almost wholly insensitive to the presence of cRGD. This result suggests that Gel in the mixture with $\mathrm{Col}$ does not significantly influence the nature of the integrin specific binding of cells expressing both $\mathrm{Col}$ and Gel-recognition integrins. The adhesion of $\mathrm{C} 2 \mathrm{C} 12$ parent cells on Gel films confirms the importance of the conformation and hence the appropriate exposure of the binding ligands in producing integrin-mediated cell-substrate interactions. The results show that in Gel films the configuration of the linear RGD motif was recognisable by cells (leading to cell adhesion), while in monolayer coated surfaces this ligand seems is apparently not detectable by cell surface integrins (no attachment, no spreading).

Crosslinking strongly decreases integrin-promoted cell binding to all films, which indicates that important cell recognition sequences, vital for cell-substrate interactions, were consumed in EDC-promoted crosslinking. These results are in agreement with our recent reports [15, 32, 44], which showed that carbodiimide treatment of collagenous materials may significantly decrease the content of carboxylic groups on glutamate and aspartate amino acid residues, leading to decrease of platelet attachments on highly crosslinked Col-based biomaterials.

\subsection{Adhesion on scaffolds in comparison with films}

The 3D scaffolds used for cell attachment tests have been previously characterised in terms of morphology, dissolution properties and swelling, which are important structural determinants of biological activity on protein matrices [6, 10]. Scaffold morphology, and especially pore size, influences not only 3D dimensional parameters, which control cell migration (as, for example, percolation diameter [6]), but also affects the specific surface and, as a consequence, the ligand density on scaffold struts available for cell binding [10]. During cell culture, swelling kinetics, and degradation rates control the degree of media uptake and stability of scaffold structure, respectively, which are likely to influence cell-substrate interactions. SEM analysis of scaffolds showed that crosslinking with EDC and/or the addition of Gel to Col had no significant effect on scaffold inner structure: all protein matrices used in cell experiments 
possessed a very similar morphology with homogeneous interconnected inner architecture and the pore diameters typically between 130-260 $\mu \mathrm{m}$ [15], these being suitable for the growth of myocytes, fibroblasts, and other cells [45, 46]. Swelling profiles and dissolution behaviour of all $100 \%$ EDC XL scaffolds (from pure Col to pure Gel) were also comparable during the early stages of incubation (unpublished results): 3D constructs reached the maximum swelling after $1-2 \mathrm{~h}$ of soaking in aqueous media and all $100 \%$ EDC XL samples exhibited similar structural stability (during incubation period covering completely the duration of cell adhesion assays on scaffolds [15]). Due to similarity in scaffold inner architecture and in swelling/dissolution characteristics, the differences found in cell behaviour on scaffolds were attributed to changes in base protein (addition of Gel to $\mathrm{Col}$ ) or to the consequence of EDC crosslinking but not to the differences in scaffold morphology or their physical properties.

The results of adhesion studies on scaffolds revealed that the addition of Gel to Col produced an effect on cell attachment on 3D matrices very similar to that found on films. However, there was a very substantial difference between cell adhesion profiles on 2D films and 3D scaffolds: only integrin mediated binding was a characteristic feature of films, while 3D scaffolds showed a high level of non-specific interactions for all compositions and cell lines. This non-specific (in presence of EDTA) adhesion on scaffolds increased with the extent of crosslinking and may be attributed to cell entrapment within scaffold struts. It is possible that EDTA promoted non-specific cell binding was also present in 2D films but was completely removed by a rigorous washing treatment applied to these systems after cell attachment. However, in scaffolds this non integrinmediated cell bonding remained, even after extended washing procedure, as a result of the contribution of sponge-like architecture to the entrapment of weakly bound cells. It seems that this phenomenon is dependent on the degree of intra/inter-molecular bond formation in $\mathrm{Col}$ fibrils, promoted by EDC crosslinking. The level of this non-integrin-dependent attachment should be considered for the correct evaluation of the biological performance of 3D scaffolds, since it has been reported that non-specific cellbinding on biopolymer surfaces does not lead to further regenerative activity of TE cell-scaffolds constructs [10].

The studies on films and scaffolds show that the integrindependent cellular response was highly dependent on the specific cell type and on the nature and amount of the adhesion motifs on the substrate. It was demonstrated that chemical crosslinking via the carbodiimide procedure, which is widely used in scaffold design for the purpose of enhancing physical and mechanical properties, ablates $\mathrm{Mg}$ dependent integrin-binding cell activity on samples with both 2D (films) and 3D (scaffolds) architectures. This effect

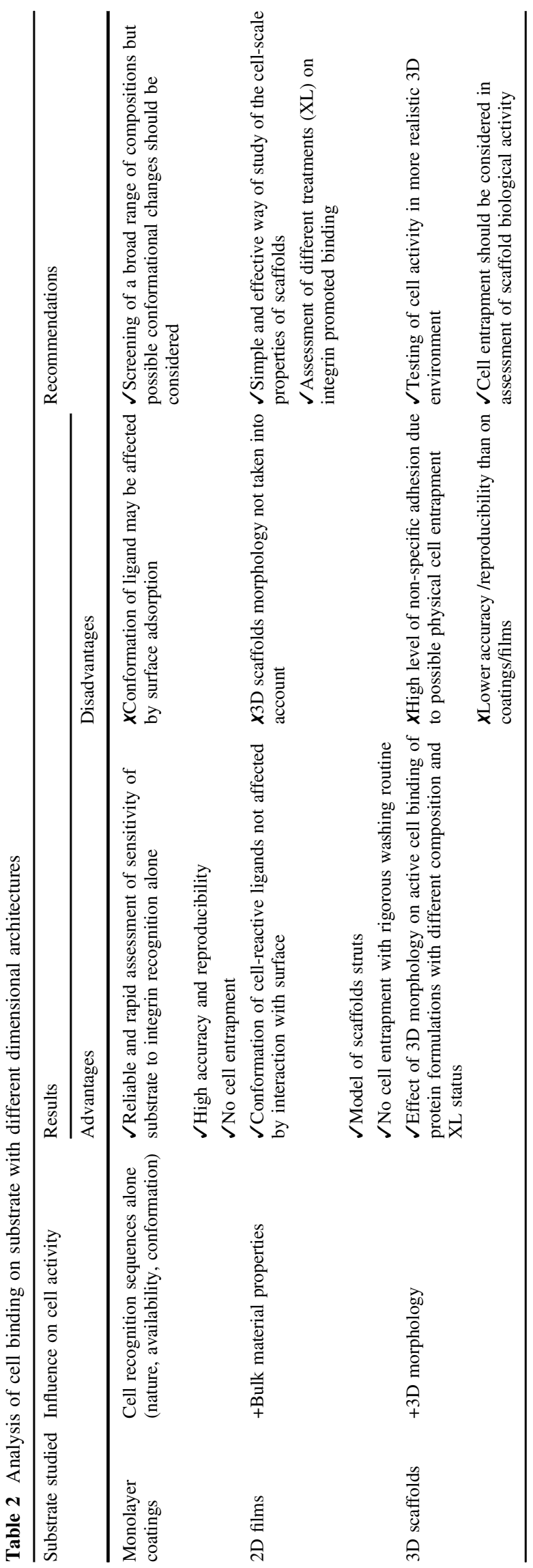


of EDC-mediated crosslinking may be attributed to the consumption of carboxylic groups on glutamate and/or aspartate residues in the native $\mathrm{Col}$ and Gel sequences, these being crucial for cell-substrate interactions.

\subsection{The most characteristic features of cell adhesion on surfaces, films, and scaffolds}

The experimental approach based on a systematic increase of the complexity of substrate under study (from monolayer coatings to thin films and finally to $3 \mathrm{D}$ scaffolds) used in this work shows the potential for deconvoluting the influence of the chemical identity of cell-recognition sequences from the effect of the bulk material and dimensional properties (2D vs. 3D architecture) on the nature and extent of cell-substrate interactions on protein-derived materials. The results obtained may be summarized as shown in Table 2, where strong and weak points of each system (monolayers, films, and scaffolds) are emphasized.

\section{Conclusions}

Coated surfaces provide a reliable and rapid assessment of sensitivity of a molecular substrate to integrin recognition alone but the conformation and hence exposure of biological motifs may be compromised by their close interaction with the underlying surfaces, especially for the denatured Gel. The conformation of cell-reactive ligands is not affected by surface contact on films so that these $2 \mathrm{D}$ systems may provide a reliable way of screening a broad range of compositions and treatments such as crosslinking on integrin-specific cell binding. The adhesion on 3D scaffolds revealed that sponge-like morphology seems to be responsible for a high level of non-integrin specific interactions on crosslinked samples, which should be considered when assessing the biological activity of 3D substrates. By systematically altering the composition, crosslinking, and 2D or 3D architecture of the substrate we provide simple, but effective, means to assess separately the contribution of the effects of morphology, physical parameters, and chemistry (available binding sites) on the cell activity of proteinderived materials. This information is important in the effective design of optimised surface chemistries in scaffolds for tissue repair.

Acknowledgements The authors would like to thank the British Heart Foundation (Grants NH/11/1/28922, RG/15/4/31268 and SP/15/ 7/31561), The Welcome Trust (Grant 094470/Z/10/Z), the ERC Advanced Grant 320598 3D-E and EPSRC Doctoral Training Account for providing financial support for this project. D. V. Bax is funded by the Peoples Programme of the EU 7th Framework Programme (RAE no: PIIF-GA-2013-624904) and was also supported by an EPSRC IKC
Proof of Concept Award. The underlying data for this article may be found at: http://dx.doi.org/10.17863/CAM.693.

\section{Compliance with ethical standards}

Conflict of interest The authors declare that they have no competing interests.

Open Access This article is distributed under the terms of the Creative Commons Attribution 4.0 International License (http://creativecommons.org/licenses/by/4.0/), which permits unrestricted use, distribution, and reproduction in any medium, provided you give appropriate credit to the original author(s) and the source, provide a link to the Creative Commons license, and indicate if changes were made.

\section{References}

1. Leor J, Amsalem Y, Cohen S. Cells, scaffolds, and molecules for myocardial tissue engineering. Pharmacol Ther. 2005;105:151-63. doi:10.1016/j.pharmthera.2004.10.003.

2. Chen Q-Z, Harding SE, Ali NN, Lyon AR, Boccaccini AR. Biomaterials in cardiac tissue engineering: ten years of research survey. Mater Sci Eng R Reports. 2008;59:1-37. doi:10.1016/j. mser.2007.08.001.

3. O'Brien FJ. Biomaterials \& scaffolds for tissue engineering. Mater Today. 2011;14:88-95. doi:10.1016/S1369-7021(11)70058-X.

4. Emmert MY, Hitchcock RW, Hoerstrup SP. Cell therapy, 3D culture systems and tissue engineering for cardiac regeneration. Adv Drug Deliv Rev. 2014;69-70:254-69. doi:10.1016/j. addr.2013.12.004.

5. Grover CN, Farndale RW, Best SM, Cameron RE. The interplay between physical and chemical properties of protein films affects their bioactivity. J Biomed Mater Res-Part A. 2012;100 A:2401-11. doi:10.1002/jbm.a.34187.

6. Ashworth JC, Mehr M, Buxton PG, Best SM, Cameron RE. Cell invasion in collagen scaffold architectures characterized by percolation theory. Adv Healthc Mater. 2015;4:1317-21. doi:10.1002/adhm.201500197.

7. Tallawi M, Rosellini E, Barbani N, Cascone MG, Rai R, SaintPierre G, et al. Strategies for the chemical and biological functionalization of scaffolds for cardiac tissue engineering: a review. J R Soc Interface. 2015;12. doi:10.1098/rsif.2015.0254.

8. Harley BAC, Gibson LJ. In vivo and in vitro applications of collagen-GAG scaffolds. Chem Eng J. 2008;137:102-121. doi:10.1016/j.cej.2007.09.009.

9. Murphy CM, Haugh MG, O'Brien FJ. The effect of mean pore size on cell attachment, proliferation and migration in collagenglycosaminoglycan scaffolds for bone tissue engineering. Biomaterials. 2010;31:461-6. doi:10.1016/j. biomaterials.2009.09.063.

10. Yannas IV, Tzeranis DS, Harley BA, So PTC. Biologically active collagen-based scaffolds: advances in processing and characterization. Philos Trans $R$ Soc A Math Phys Eng Sci. 2010;368:2123-39. doi:10.1098/rsta.2010.0015.

11. Ahmad Z, Shepherd JH, Shepherd DV, Ghose S, Kew SJ, Cameron RE, et al. Effect of 1-ethyl-3-(3-dimethylaminopropyl) carbodiimide and $\mathrm{N}$-hydroxysuccinimide concentrations on the mechanical and biological characteristics of cross-linked collagen fibres for tendon repair. Regen Biomater. 2015;2:77-85. doi:10.1093/rb/rbv005.

12. Mullen LM, Best SM, Ghose S, Wardale J, Rushton N, Cameron RE. Bioactive IGF-1 release from collagen-GAG scaffold to 
enhance cartilage repair in vitro. J Mater Sci Mater Med. 2015;26:1-8. doi:10.1007/s10856-014-5325-y.

13. Campbell JJ, Botos L-A, Sargeant TJ, Davidenko N, Cameron RE, Watson CJ. A 3-D in vitro co-culture model of mammary gland involution. Integr Biol. 2014;6:618-26. doi:10.1039/ c3ib40257f.

14. Grover CN, Cameron RE, Best SM. Investigating the morphological, mechanical and degradation properties of scaffolds comprising collagen, gelatin and elastin for use in soft tissue engineering. J Mech Behav Biomed Mater. 2012;10:62-74. doi:10.1016/j.jmbbm.2012.02.028.

15. Davidenko N, Schuster CF, Bax DV, Raynal N, Farndale RW, Best SM, et al. Control of crosslinking for tailoring collagen-based scaffolds stability and mechanics. Acta Biomater. 2015;25:131-42. doi:10.1016/j.actbio.2015.07.034.

16. Lee $\mathrm{CH}$, Singla A, Lee Y. Biomedical applications of collagen. Int J Pharm. 2001;221:1-22. doi:10.1016/S0378-5173(01)00691-3.

17. Li RK, Yau TM, Weisel RD, Mickle DA, Sakai T, Choi AJZ. Construction of a bioengineered cardiac graft. J Thorac Cardiovasc Surg. 2000;119:368-75.

18. Zimmermann WH, Schneiderbanger K, Schubert P, Didié M, Münzel F, Heubach JF, et al. Tissue engineering of a differentiated cardiac muscle construct. Circ Res. 2002;90:223-30. doi:10.1161/hh0202.103644.

19. Lowry OH, Guilligan DRKE. The determination of collagen and elastin in tussues with results obtained in various normal tissues from different species. J Biol Chem. 1941;139:795-804.

20. Siljander PRM, Hamaia S, Peachey AR, Slatter DA, Smethurst $\mathrm{PA}$, Ouwehand $\mathrm{WH}$, et al. Integrin activation state determines selectivity for novel recognition sites in fibrillar collagens. J Biol Chem. 2004;279:47763-72. doi:10.1074/jbc.M404685200.

21. Pugh N, Simpson AMC, Smethurst PA, De Groot PG, Raynal N, Farndale RW. Synergism between platelet collagen receptors defined using receptor-specific collagen-mimetic peptide substrata in flowing blood. Blood. 2010;115:5069-79. doi:10.1182/blood2010-01-260778.

22. Knight CG, Morton LF, Onley DJ, Peachey AR, Messent AJ, Smethurst PA, et al. Identification in collagen type I of an integrin alpha2beta1-binding site containing an essential GER sequence. J Biol Chem. 1998;273:33287-94. doi:10.1074/jbc.273.50.33287.

23. Davis GE. Affinity of integrins for damaged extracellular matrix: alpha $\mathrm{v}$ beta 3 binds to denatured collagen type I through RGD sites. Biochem Biophys Res Commun. 1992;182:1025-31. doi:10.1016/0006-291X(92)91834-D.

24. Cole C. Gelatin. Encyclopedia of food science and Technology Frederick JFR. ed. New York: John Wiley Sons, 2000, p. 1183-88.

25. Davidenko N, Bax DV, Schuster CF, Farndale RW, Hamaia S, Serena M, Best REC. Optimisation of UV irradiation as a binding site conserving method for crosslinking collagen-based scaffolds. J Mater Sci Mater Med. 2016;27:1-17.

26. Hynes RO. Integrins: bidirectional, allosteric signaling machines. Cell. 2002;110:673-87. doi:10.1016/S0092-8674(02)00971-6.

27. Barczyk M, Carracedo SGD. Integrins. Cell Tissue Res. 2010;339:269-80.

28. Pieper JS, Oosterhof A, Dijkstra PJ, Veerkamp JH, van Kuppevelt TH. Preparation and characterization of porous crosslinked collagenous matrices containing bioavailable chondroitin sulphate. Biomaterials. 1999;20:847-58. doi:10.1016/S0142-9612(98) 00240-3.

29. Olde Damink LH, Dijkstra PJ, van Luyn MJ, van Wachem PB, Nieuwenhuis P, Feijen J. Cross-linking of dermal sheep collagen using a water-soluble carbodiimide. Biomaterials. 1996;17:765-73. doi:10.1016/0142-9612(96)81413-X.
30. Davidenko N, Campbell JJ, Thian ES, Watson CJ, Cameron RE. Collagen-hyaluronic acid scaffolds for adipose tissue engineering. Acta Biomater. 2010;6:3957-68. doi:10.1016/j. actbio.2010.05.005.

31. Pieper JS, Hafmans T, Veerkamp JH, van Kuppevelt TH. Development of tailor-made collagen-glycosaminoglycan matrices: EDC/NHS crosslinking, and ultrastructural aspects. Biomaterials. 2000;21:581-93. doi:10.1016/S0142-9612(99)00222-7.

32. Grover CN, Gwynne JH, Pugh N, Hamaia S, Farndale RW, Best $\mathrm{SM}$, et al. Crosslinking and composition influence the surface properties, mechanical stiffness and cell reactivity of collagenbased films. Acta Biomater. 2012;8:3080-90. doi:10.1016/j. actbio.2012.05.006.

33. Enea D, Henson F, With A, Kew S, Wardale J, Getgood A, et al. Extruded collagen fibres for tissue engineering applications: effect of crosslinking method on mechanical and biological properties. J Mater Sci Mater Med. 2011;22:1569-78.

34. Knight CG, Morton LF, Peachey AR, Tuckwell DS, Farndale RW, Barnes MJ. The collagen-binding A-domains of integrins alpha(1)beta(1) and alpha(2)beta(1) recognize the same specific amino acid sequence, GFOGER, in native (triple-helical) collagens. J Biol Chem. 2000;275:35-40. doi:10.1074/jbc.275.1.35.

35. Elliott JT, Woodward JT, Langenbach KJ, Tona A, Jones PL, Plant AL. Vascular smooth muscle cell response on thin films of collagen. Matrix Biol. 2005;24:489-502. doi:10.1016/j. matbio.2005.07.005.

36. Xiong J-P, Stehle T, Zhang R, Joachimiak A, Frech M, Goodman SL, et al. Crystal structure of the extracellular segment of integrin alpha Vbeta3 in complex with an Arg-Gly-Asp ligand. Science. 2002;296:151-55. doi:10.1126/science.1069040.

37. Emsley J, Knight CG, Farndale RW, Barnes MJ, Liddington RC. Structural basis of collagen recognition by integrin alpha2beta1. Cell. 2000;101:47-56. doi:10.1016/S0092-8674(00)80622-4.

38. Luo B-H, Carman CV, Springer TA. Structural basis of integrin regulation and signaling. Annu Rev Immunol. 2007;25:619-47. doi:10.1146/annurev.immunol.25.022106.141618.

39. Raynal N. Use of synthetic peptides to locate novel integrin 2beta1-binding motifs in human collagen III. J Biol Chem. 2006;281:3821-31. doi:10.1074/jbc.M509818200.

40. Brodsky BRJ. The collagen friple-helix structure. Matrix Biol. 1997;15:545-54.

41. Brodsky B, Thiagarajan G, Madhan B, Kar K. Triple-helical peptides: an approach to collagen conformation, stability, and selfassociation. Biopolymers. 2008;89:345-53. doi:10.1002/ bip. 20958.

42. Hamaia SFR. Integrin recognition motifs in the human collagens. Adv Exp Med Biol. 2014;819:127-42.

43. Main AL, Harvey TS, Baron M, Boyd J, Campbell ID. The threedimensional structure of the tenth type III module of fibronectin: an insight into RGD-mediated interactions. Cell. 1992;71:671-78. doi:10.1016/0092-8674(92)90600-H.

44. Malcor JD, Bax D, Hamaia SW, Davidenko N, Best SM, Cameron $\mathrm{RE}$, et al. The synthesis and coupling of photoreactive collagenbased peptides to restore integrin reactivity to an inert substrate, chemically-crosslinked collagen. Biomaterials. 2016;85:65-77. doi:10.1016/j.biomaterials.2016.01.044.

45. Radisic M, Vunjak-Novakovic G. Cardiac tissue engineering. J Serb Chem Soc. 2005;70:541-56.

46. Wang B, Borazjani A, Tahai M, Curry AL, de J, Simionescu DT, Guan J, et al. Fabrication of cardiac patch with decellularized porcine myocardial scaffold and bone marrow mononuclear cells. J Biomed Mater Res A. 2010;94:1100-10. doi:10.1002/jbm. a.32781. 